\title{
Blood and Gut Micriobiota Profiles of Broiler Chickens Fed on Diet Supplemented with Graded Levels of Neem (Azadirachta indica) Oil
}

\author{
Mafouo Sonhafouo Vanessa*, Kana Jean Raphaël, Nguepi Ndogmo Kissel \\ Animal Nutrition and Production Research Unit, Department of Animal Science, University of Dschang, Dschang, Cameroon
}

Email address:

vanessa.sonhafouo@yahoo.fr (M. S. Vanessa)

${ }^{*}$ Corresponding author

\section{To cite this article:}

Mafouo Sonhafouo Vanessa, Kana Jean Raphaël, Nguepi Ndogmo Kissel. Blood and Gut Micriobiota Profiles of Broiler Chickens Fed on Diet Supplemented with Graded Levels of Neem (Azadirachta indica) Oil. Animal and Veterinary Sciences.

Vol. 7, No. 3, 2019, pp. 78-82. doi: 10.11648/j.avs.20190703.12

Received: April 17, 2019; Accepted: June 5, 2019; Published: June 26, 2019

\begin{abstract}
The present study was assigned to evaluate the Hematological and gut micriobiota profiles of broiler chickens fed on diet supplemented with graded levels of neem oil. A total of 400 day-old chicks of Cobb 500 strain were randomly assigned to 5 treatments groups of 80 birds each with 5 replicates. The experimental rations consisted of a control diet without supplement (R0-), a positive control diet containing $1 \mathrm{~g}$ of antibiotic/kg (R0+) and three other diets supplemented respectively with 15, 20 and $25 \mathrm{~g}$ of neem oil / $\mathrm{kg}$ of feed. Feeding broiler with neem oil had no significant $(\mathrm{p}<0.05)$ effect on heamoglobin (Hb), Packed cell volume (PCV), Red blood cell (RBC), total leucocytes, white blood cells (WBC), mean corpuscular volume (MCV), mean corpuscular haemoglobin (MCH), mean corpuscular haemoglobin concentration (MCHC) and lymphocytes counts. With $25 \mathrm{~g}$ of oil / $\mathrm{kg}$ no trace of salmonella has found in the digestive tract. While, shigellae count was significantly lower with $20 \mathrm{~g}$ of neem / $\mathrm{kg}$ feed compared to the negative control diet. It was concluded that up to $20 \mathrm{~g}$ of neem could be included in a $\mathrm{kg}$ of broiler chickens diet without deleterious effect on their blood constituents and with the benefit of reducing possible risks of infection from pathogenic bacteria.
\end{abstract}

Keywords: Neem Oil, Hematology, Bacterial Counts, Broiler Chickens

\section{Introduction}

The use of synthetic antibiotics as growth promoters has high cost implications and adverse side effect on bird's health, prolonged withdrawal period and risk of accumulation in tissues and egg which could have harmful effects on human health [1]. As a result, consumers of poultry products are demanding for drug residues free meat. This has triggered the search for alternatives means to produce birds at reduced cost using natural growth and health promoters. Studies of neem (Azadirachta indica) indicate an increasing interest in the plant owing to its versatile application and promising uses.

Neem (Azadirachta indica), popularly known as Indian neem (margosa) or Indian lilac of the family Maliaceae, is one of such non-conventional and available ingredients sources in the tropics with great potential. It is a tropical tree plant which is widely distributed in Africa and available all year round $[2,3]$. The tree is well adapted to the climatic and soil conditions in the tropical rainforest regions, all the way to the Sahel savannah part of Cameroon. The leaves are very bitter to taste, and possess a garlic-like smell. The plant is popular because it is readily available, cheap, non-toxic to animals and humans and efficacious against malaria [3].

A. indica seed oil contains triterpenoid compounds such as azadirachtin, gedunine, nimbine and nimbidine which have antibacterial and antifungal properties $[4,5]$. The blend of these compounds in poultry feed can produces additive or synergistic effects on production performance [5]. The antimicrobial activity of extracts of neem leaves against such micro-organisms as Staphylococcus spp, Streptococcus spp, Pseudomonas spp and Escherichia coli, and some fungal strains have been reported $[3,5]$. Studies on the effects of neem leaves on poultry production especially of broilers and 
laying hens also exist $[6,7]$. Antimicrobial studies on the effects of neem leaves and their extracts on cultured microorganisms in vitro have also been carried out [3].

However, there is no information on the performance, the heatlh and the physiological conditions of animal fed on neem oil. The present study was therefore undertaken to investigate the effects of graded levels of neem oil on the hematological profiles and gut microbial counts of broiler chickens.

\section{Materials and Methods}

\subsection{Study Area}

This study was carried out at the Poultry Unit of the Teaching and Research Farm of the Faculty of Agronomy and Agricultural Sciences of the University of Dschang, Cameroon. Dschang is located in the West region of Cameroon at $05^{\circ} 26^{\prime} \mathrm{N}$ and $10^{\circ} 26^{\prime} \mathrm{E}$. The area experiences a wet season from March to November and a hot dry season for the rest of the year. Maximum ambient temperature is around $21^{\circ} \mathrm{C}$, while an average annual rainfall of $2000 \mathrm{~mm}$ is prevalent.

\subsection{Processing of Neem Oil and Experimental Rations}

Fresh neem fruits were collected at Garoua in the Northern Region of Cameroon between September and October 2017. They were thoroughly washed with running tap water and separated from the sheet manually. The seeds were oven dried at $50^{\circ} \mathrm{C}$ until constant moisture content was achieved. The dried seeds were ground in a mill for size reduction and the extraction of oil was carried out by kneading the paste. The phytochemical analyses of neem oil carried out as described by Talukdar et al. [8] revealed that alkaloids, flavonoids, terpenoids, phenols, steroids and tannins were presents.

Experimental diet consisted of control ration without no supplement $\left(\mathrm{R}_{0}^{-}\right)$, positive control supplemented with $1 \mathrm{~g}$ of antibiotic $/ \mathrm{kg}$ of feed $\left(\mathrm{R}_{0}^{+}\right)$and 3 others rations supplemented with $15 \mathrm{~g}\left(\mathrm{R}_{15}\right), 20 \mathrm{~g}\left(\mathrm{R}_{20}\right)$ and $25 \mathrm{~g}\left(\mathrm{R}_{25}\right)$ of neem oil $/ \mathrm{kg}$ of feed. The antibiotic used in positive control ration was Doxycycline ${ }^{\circledR}$. The proximate composition of the basal diet is summarized in Table 1.

Table 1. Composition of the basal diet.

\begin{tabular}{lll}
\hline Ingredients (\%) Starter & & Finisher \\
\hline Maize & 59 & 65 \\
Remoulage & 5 & 5 \\
Cotton seed cake $(50 \%)$ & 6 & 4 \\
Soybean meal $(49 \%)$ & 20 & 15 \\
Fish meal $(60 \%)$ & 4 & 5 \\
Shellfish & 0.75 & 1 \\
Bone meal & 0.25 & 0 \\
Premix 5\%* & 5 & 5 \\
Total & 100 & 100 \\
Analysed composition & & \\
Metabolizable energy $(\mathrm{kcal} / \mathrm{kg})$ & 2951.91 & 3006.85 \\
Crude protein $(\%)$ & 22.53 & 20.38 \\
Calculated composition & & \\
\hline
\end{tabular}

\begin{tabular}{lll}
\hline Ingredients (\%) Starter & & Finisher \\
\hline Energy/Protéin & 130.99 & 147.54 \\
Lysine (\%) & 1.32 & 1.19 \\
Methionine (\%) & 0.46 & 0.45 \\
Calcium (\%) & 1.07 & 1.15 \\
Non-phytate phosphorus (\%) & 0.5 & 0.48 \\
Calcium/phosphore & 2.16 & 2.41 \\
Crude fibers (\%) & 4.96 & 4.94 \\
Price/kg (FCFA) & 273.59 & 147.54 \\
\hline
\end{tabular}

* Premix: Mineral Nitrogen and Vitamin Complex: Crude protein $=40 \%$, Calcium $=8 \%$, Phosphorous $=2.05 \%$, Lysine $=3.3 \%$, Methionine $=2.40 \%$, $\mathrm{ME}=2078 \mathrm{Kcal} / \mathrm{kg}$, Vit A: 3,000,000UI, Vit D 3: 600,000UI, Vit E: 4,000mg, Vit K: 500mg, Vit B1: 200mg, VitB2: 1000mg, Vit B6: 400mg, Vit B12: 4mg, Iron: $8000 \mathrm{mg}, \mathrm{Cu}: 2000 \mathrm{mg}, \mathrm{Zn}: 10,000 \mathrm{mg}$, Se: 20mg, Mn: $14000 \mathrm{mg}$

\subsection{Experimental Birds}

A total of 400-day-old Cobb 500 strain chicks with an average body weight of $38.53 \mathrm{~g}$ obtained from a local hatchery has provided with ad libitum access to feed and water. Birds were given vaccines in drinking water against Newcastel disease and Infectious Bronchitis on the 8th day with a booster dose on the 23th day of age, and against Gumboro disease on the 10th day of age. Coccidiosis prevention was done using Vetacox ${ }^{\circledR}$ for 3 consecutive days per week from the 2 nd to the 6 th week of age. Birds were administered commercial antistress (Amintotal ${ }^{\mathbb{R}}$ : LAPROVET, Tours Cedrex 2, France) in drinking water during the first 3 days upon arrival, after each vaccination, weighing session and transfer from brooding house to finishing house.

The birds were weighed at the beginning of the experiment and at weekly intervals thereafter. The birds were randomly assigned to the five treatment dietary groups (R0+, R0-, R15, R20 and R25) of 80 birds each. Each treatment was further divided into five (5) replicates of sixteen (16) birds and places in pens in line with the design of the experiment.

\subsection{Hematological Parameters}

At 7 weeks, ten birds ( 05 males and 05 females) from each treatment were randomly selected for bleeding. $3 \mathrm{~mL}$ of the blood was collected from each bird into a tube containing EDTA as anticoagulant, and shaken gently to prevent coagulation. Blood samples were immediately analyse for hematological parameters using routine laboratory procedures as described by Schalm et al. [9] Saror and Schillhorn van Veen [10], Friedman and Young [11], Iyayi and Tewe [12]. The hemoglobin ( $\mathrm{Hb})$ content was determined with a digital photo colorimeter (Model 312E by Digital Photo Instruments, Germany) at a wavelength of $625 \mathrm{~nm}$ and expressed in gram (g) units. Packed cell volume (PCV) was determined through the Winthrose microhaematocrit technique, and expressed in percentages (\%). Red blood cell (RBC) counts were obtained with a Coulter Electronic counater (Model ZF by Coulter Electronic Ltd. London), and the values expressed in millions per microlitre $(\mu \mathrm{L})$ of blood $\left(\times 10^{6} / \mu \mathrm{L}\right)$. The white blood cells (WBC) were counted with an improved Neubauer 
hemocytometer and expressed in thousands per microlitre $(\mu \mathrm{L})$. Other hematological parameters computed or evaluated included mean corpuscular volume (MCV), mean corpuscular haemoglobin $(\mathrm{MCH})$, and mean corpuscular haemoglobin concentration (MCHC) and lymphocytes counts.

\subsection{Gut Microbiota Count}

Sterile forceps were used to collect the faecal samples from each treatment group from the dropping tray into anal swab. Microbial count and identification were done using routine laboratory procedures outlined by Duraipandiyan et al. [5], Tuhin et al. [13] and Valarmathy et al. [14]. The analysis included preparation of culture media, microscopic and macroscopic examination of the faecal samples, and growth/population counts. Total Bacteria Counts were then determined. All glassware used were thoroughly washed with detergent, rinsed with distilled water, wrapped in aluminum foil and sterilized in a hot air oven at $125^{\circ} \mathrm{C}$ for 1 hour.

\subsection{Data Analysis}

Data collected were subjected to one-way analysis of variance (ANOVA) according to the procedure of Steel and Torrie [15]. Where ANOVA indicated significant different treatment means, they were separated using the Duncan's New Multiple Range Test at 5\% [16].

\section{Results}

The summary of the effects of inclusion levels of neem on the hematological parameters of the broiler chickens is presented in Table 2. The analysis of variance revealed no significant $(p>0.05)$ difference between treatment groups regardless of the characteristics evaluated. However, although not significant, the number of white blood cells, granulocytes, blood platelet count (PLT) and platelets (PCT) tend to increase with the increasing level of neem oil in the ration.

Table 2. Effects of graded level of neem oil in the ration on the hematological parameters of broiler chickens.

\begin{tabular}{|c|c|c|c|c|c|c|}
\hline \multirow{2}{*}{ Hematological characteristics } & \multicolumn{2}{|l|}{ Control } & \multicolumn{3}{|c|}{ Neem oil (g / kg of food) } & \multirow[b]{2}{*}{$p$} \\
\hline & $\mathbf{R}_{0}^{-}$ & $\mathbf{R}_{\mathbf{0}}^{+}$ & 15 & 20 & 25 & \\
\hline WBC $\left(10^{3} \mu \mathrm{l}\right)$ & $9.29 \pm 5.45$ & $6.5 \pm 1.31$ & $7.83 \pm 1.57$ & $8.50 \pm 2.64$ & $8.94 \pm 5.13$ & 0.644 \\
\hline LYM $\left(10^{3} \mu \mathrm{l}\right)$ & $4.80 \pm 1.53$ & $2.98 \pm 0.72$ & $2.87 \pm 0.76$ & $2.85 \pm 0.93$ & $2.96 \pm 1.75$ & 0.409 \\
\hline GRAN $\left(10^{3} \mu 1\right)$ & $3.36 \pm 1.54$ & $2.84 \pm 1.31$ & $3.84 \pm 0.68$ & $4.57 \pm 1.56$ & $4.80 \pm 1.90$ & 0.394 \\
\hline $\operatorname{RBC}\left(10^{6} \mu \mathrm{l}\right)$ & $3.66 \pm 0.49$ & $4.10 \pm 0.41$ & $4.12 \pm 0.49$ & $4.94 \pm 1.97$ & $4.15 \pm 0.32$ & 0.185 \\
\hline $\mathrm{Hb}(\mathrm{g} / \mathrm{dl})$ & $12.10 \pm 2.22$ & $13.44 \pm 2.44$ & $13.23 \pm 1.63$ & $16.35 \pm 6.16$ & $13.96 \pm 1.76$ & 0.190 \\
\hline HCT (\%) & $30.36 \pm 4.97$ & $33.17 \pm 5.79$ & $33.10 \pm 5.28$ & $40.43 \pm 5.78$ & $34.95 \pm 4.33$ & 0.245 \\
\hline MCV (fL) & $83.00 \pm 5.99$ & $80.58 \pm 9.40$ & $80.78 \pm 11.53$ & $82.31 \pm 12.37$ & $84.46 \pm 8.94$ & 0.939 \\
\hline $\mathrm{MCH}(\mathrm{pg})$ & $32.89 \pm 2.30$ & $32.54 \pm 4.07$ & $32.30 \pm 3.88$ & $33.31 \pm 4.27$ & $33.64 \pm 3.70$ & 0.957 \\
\hline $\mathrm{MCHC}(\mathrm{g} / \mathrm{dl})$ & $39.84 \pm 3.25$ & $40.44 \pm 1.46$ & $40.21 \pm 3.09$ & $40.65 \pm 1.42$ & $39.91 \pm 1.94$ & 0.955 \\
\hline $\operatorname{PLT}\left(10^{3} \mu 1\right)$ & $24143 \pm 128.89$ & $176 \pm 76.25$ & $198.86 \pm 48.55$ & $210.50 \pm 102.72$ & $294.25 \pm 145.76$ & 0.267 \\
\hline PCT $(\%)$ & $0.30 \pm 0.15$ & $0.22 \pm 0.09$ & $0.25 \pm 0.05$ & $0.26 \pm 0.14$ & $0.38 \pm 0.19$ & 0.241 \\
\hline
\end{tabular}

R0-: 0g of neem oil / kg of food; R0 +: R0- + 1g of Doxycicline / kg of food; p: Probability WBC: white blood cells; Lym: lymphocytes; Gran: granulocytes; RBC: red blood cells; Hb: hemoglobin; HCT: hematocrit; PLT: platelet count; PCT: plaquettocrite; MCH: mean corpuscular hemoglobin; MCHC: Mean corpuscular concentration of hemoglobin.

The bacteria count was significantly $(\mathrm{p}<0.05)$ affected by the increasing level of neem oil (Table 3 ). The animals fed on diet supplemented with $25 \mathrm{~g}$ of neem oil / $\mathrm{kg}$ were not infested with salmonella, while the number of Salmonella colonies was significantly higher $(p<0.05)$ in chickens fed on the control diet without supplement. The supplementation of the rations with neem oil whatever the doses stimulated the multiplication $(\mathrm{p}<0.05)$ of lactobacilli compared to the negative control diet. The number of shigellae recorded in animals supplemented with $20 \mathrm{~g}$ of neem oil / $\mathrm{kg}$ of feed was significantly lower compared to the number induced by the control diet without supplement. The Escherichia coli counts recorded in chickens fed on different levels of neem oil was statistically $(p<0.05)$ higher compared to the chickens fed antibiotic medicated diet (Table 3).

Table 3. Variation of gut bacteria (CFU/ swab) of the broiler fed on graded levels of neem oil supplemented diet.

\begin{tabular}{|c|c|c|c|c|c|c|}
\hline \multirow{2}{*}{ Number of bacteria colony ( $\log 10 \mathrm{CFU} / \mathrm{swab})$} & \multicolumn{2}{|l|}{ Control } & \multicolumn{3}{|c|}{ Neem oil (g/ kg of food) } & \multirow[b]{2}{*}{$p$} \\
\hline & $\mathbf{R}_{0-}$ & $\mathbf{R}_{\mathbf{0}^{+}}$ & 15 & 20 & 25 & \\
\hline Escherichia coli & $4.65 \pm 0.46^{\mathrm{a}}$ & $3.80 \pm 0.49^{\mathrm{b}}$ & $4.62 \pm 0.70^{\mathrm{a}}$ & $4.98 \pm 0.60^{\mathrm{a}}$ & $4.66 \pm 0.19^{\mathrm{a}}$ & 0.061 \\
\hline Salmonella & $1.53 \pm 0.70^{\mathrm{a}}$ & $0.62 \pm 0.13^{\mathrm{a}}$ & $1.51 \pm 0.17^{\mathrm{a}}$ & $0.85 \pm 0.19^{\mathrm{a}}$ & $0.00 \pm 0.00^{b}$ & 0.055 \\
\hline Shigella & $5.27 \pm 0.55^{\mathrm{a}}$ & $3.28 \pm 1.32^{\mathrm{ab}}$ & $4.15 \pm 1.77^{\mathrm{ab}}$ & $1.19 \pm 0.38^{b}$ & $4.01 \pm 1.69^{\mathrm{ab}}$ & 0.051 \\
\hline Lactobacilli & $4.79 \pm 0.39^{\mathrm{b}}$ & $5.44 \pm 0.40^{\mathrm{ab}}$ & $5.70 \pm 0.34^{\mathrm{a}}$ & $5.67 \pm 0.82^{\mathrm{a}}$ & $5.78 \pm 0.44^{\mathrm{a}}$ & 0.059 \\
\hline
\end{tabular}

$\mathrm{a}, \mathrm{b}$ : averages with the same letter on the same line are not significantly different $(\mathrm{P}>0.05)$. R0-: $0 \mathrm{~g}$ of neem oil / $\mathrm{kg}$ of food; R0 +: R0- + 1g of Doxycicline / kg of food; $p$ : Probability

Table 4 shows that body weight and weight gain are negatively correlated with the number of bacteria regardless of the rate of oil and the type of bacteria present in the digestive tract. Moreover, regardless of the oil content, the 
feed conversion ratio is positively correlated to Salmonella and Shigella counts. At the incorporation rate of $25 \mathrm{~g}$ of neem oil $/ \mathrm{kg}$ of feed, the feed conversion ratio is significantly, strongly and positively correlated with the number of
Eschericjia coli. With $20 \mathrm{~g}$ of neem oil $/ \mathrm{kg}$, the number of Salmonella and Shigella is positively and significantly ( $\mathrm{p}$ $<0.05$ ) correlated to the the feed conversion ratio.

Table 4. Correlation coefficients between growth parameters, bacterial counts and incorporation rate of neem oil.

\begin{tabular}{|c|c|c|c|c|c|}
\hline \multirow{2}{*}{ Incorporation rate of neem oil (g/kg of feed) } & \multirow{2}{*}{ Growth parameters } & \multicolumn{4}{|l|}{ Bacteria } \\
\hline & & Escherichia coli & Salmonella $s p$ & Shigella sp & Lactobacillus sp \\
\hline \multirow{4}{*}{0} & FI & -0.310 & 0.354 & -0.310 & 0.070 \\
\hline & LW & 0.078 & 0.221 & -0.105 & -0.432 \\
\hline & WG & -0.103 & 0.297 & -0.014 & -0.566 \\
\hline & $\mathrm{FC}$ & -0.007 & -0.142 & -0.049 & 0.437 \\
\hline \multirow{4}{*}{15} & FI & 0.262 & 0.393 & 0.709 & 0.464 \\
\hline & LW & -0.633 & -0.490 & -0.477 & -0.440 \\
\hline & WG & -0.506 & -0.597 & -0.622 & -0.575 \\
\hline & $\mathrm{FC}$ & 0.502 & 0.575 & 0.614 & 0.556 \\
\hline \multirow{4}{*}{20} & FI & -0.439 & 0.705 & 0.705 & -0.005 \\
\hline & LW & 0.378 & -0.859 & -0.859 & -0.848 \\
\hline & WG & 0.362 & -0.755 & -0.755 & -0.865 \\
\hline & FC & -0.446 & $0.908^{*}$ & $0.908^{*}$ & 0.806 \\
\hline \multirow{4}{*}{25} & FI & 0.106 & $0.000^{\mathrm{a}}$ & 0.144 & 0.048 \\
\hline & LW & $-0.989^{* *}$ & $0.000^{\mathrm{a}}$ & -0.861 & 0.447 \\
\hline & WG & $-0.975^{* *}$ & $0.000^{\mathrm{a}}$ & -0.856 & 0.421 \\
\hline & $\mathrm{FC}$ & $0.915^{*}$ & $0.000^{\mathrm{a}}$ & 0.758 & -0.484 \\
\hline
\end{tabular}

*Significant at $0.05 * *$ Significant at 0.01

FI: feed intake; LW: live weight; WG: weight gain; FC: feed conversion

\section{Discussion}

Blood parameters are considered as the main pathological [17] and nutritional [18] physiological indices for assessing the state of an organism. Any change in the constituent elements of the blood relative to the normal values is an important index for the interpretation of the physiological or metabolic state of the animal but also and especially the quality of the food [19]. Decrease in red blood cells is usually associated with poor quality foods. Hemoglobin determines an animal's ability to withstand a certain level of respiratory stress and hematocrit is the proportion of blood containing red blood cells [20]. When their values are high, this characterizes a polycystemia and when they are weak, it indicate anemia [21]. In the present study, the increasing rate of neem oil tends to increase red blood cell, hematocrit and hemoglobin counts compared to the negative and positive controls groups. This result is in agreement with the feedings of Vivian et al. [22] who recorded an increase in the number of red blood cells and hemoglobin in chickens receiving aqueous extracts of ginger. Although not significant, the levels of white blood cells, lymphocytes and granulocytes tend to increase with the increasing level of this phytobiotic. This result corroborates the findings of Odoh and Lawrence [23] who reported that by incorporating 10 and $15 \%$ neem leaf powder into the broiler food this increased the content of white blood cells and lymphocytes. The increase in white blood cells could be explained by the presence of the active compounds like triterpenoids and phenols in neem oil which might play a very decisive role in stimulating the body's immune system. In this study, the values of hematological parameters observed with the incorporation of neem oil in the ration remained within the range of physiological reference values recommended by Almosni-Le Sueur et al. [24].

The lactobacilli count was significantly higher with rations supplemented with neem oil irrespective of the dose. With 25 $\mathrm{g}$ of oil / $\mathrm{kg}$ no trace of salmonella was observed in digestive tract; while, the number of shigellae recorded was significantly lower with the ration supplemented with $20 \mathrm{~g}$ of neem / kg oil compared to the negative control diet. These results are in agreement with the finding of Divya et al. [25] who reported the antibacterial effect of neem oil on several bacteria isolated from a drug-resistant human. In vitro studies conducted by Abalaka et al. [26] revealed that neem oil at 50 $\mathrm{mg}$ has inhibitory effects on the growth of Pseudomonas aeruginosa, Klebsiella ozanae, Staphylococcus aureus and Escherichia coli.

\section{Conclusion}

This study revealed that administration of neem oil to broiler chickens through feed has no significant effect on hematological parameters. However, whatever the incorporation rate, neem oil can be used as feed additive to balance gut microbiota thus ensuring a good health of the digestive tract which is a key factor of a better growth in animal.

\section{References}

[1] Jawad Z., Younus M., Rehman M. U., Munir R., Maqbool A., Shahzad W., Masood S. and MuhammadA., 2014. Effect of Azadirachta indica on the Hepatorenal functions in broilers chickens. The Journal of Animal and Plant Sciences, 24 (4): 1012-1018. 
[2] Ogbuewu I. P., Odoemenam V. U., Obikaonu H. O., Opara M. N., Emenalom O. O., Uchegbu M. C., Okoli I. C., Esonu B. O. and Iloje M. U., 2011. The Growing Importance of Neem (Azadirachta indica A. Juss) in Agriculture, Industry, Medicine and Environment: A Review. Research Journal of Medicinal Plants, 5 (3): 230-245.

[3] Koona S. and Budida S., 2011. Antibacterial Potential of the Extracts of the Leaves of Azadirachta indica Linn. Notulae Scientia Biologicae, 3 (1): 65-69.

[4] Makeri H. K., Maikai V. A, and Nok J. A., 2007. Effect of Topical Application of Neem Seed (Azadirachta indica) Extract on Sheep Infested with Amblyomma variegatum. African Journal of Biotechnology, 6 (20): 2324-2327.

[5] Valarmathy K., Gokulakrishnan Salma K. M. and Kusum D. P., 2010. A Study of Antimicrobial Activity of Ethanolic Extracts of Various Plant Leaves Against Selected Microbial Species. International Journal of Pharmacology Sciences and Research, 1 (8): 293-295.

[6] Esonu B. O. and Iloje M. U., 2011. The Growing Importance of Neem (Azadirachta indica A. Juss) in Agriculture, Industry, Medicine and Environment: A Review. Research Journal of Medicinal Plants, 5 (3):230-245.

[7] Obun C. O., Ukim C. I., Olatunji E. A. and Kehinde A. S., 2013. Health and carcass implications of dietary inclusion of graded level of sun cured Neem (Azadirachta indica, A. Jus) leaf meal for broilers. Greener Journal of Agricultural Science, 3 (1): 48-54.

[8] Talukdar, A. D., Choudhary, M. D., Chakraborty, M., Dutta BK., 2010. Phytochemical screening and TLC profiing of plant extracts Cyathea gigantea (Wall. Ex. Hook.) Haltt and Cyathea brunoniana Wall. Ex. Hook. (Cl. \& Bak.). Journal of Science and Technology: Biological and Environmental Sciences 5: 70-74.

[9] Schalm O. W., Jain N. C. and Carol, E. J., 1975. Veterinary Hematology. 3rd Edition. Lea and Febiger, Philadelphia. Pp $51-81$

[10] Saror D. I. and Schillhorn van Veen T. W., 1977. Haematological Values of Udah and Yankasa Sheep in the Northern Guinea Savanna of Nigeria. Tropical Animal Health and Production, 9 (4): 245-248.

[11] Friedman R. B. and Young D. S., 1997. Effect of Disease on Clinical Laboratory Tests. 3rd Edition. AACC Press, Washington DC.

[12] Iyayi E. A. and Tewe O. O., 1998. Serum Total Protein, Urea Creatinine Levels as Indices of Quality of Cassava Diets for Pigs. Tropical Veterinary, 16: 59-67.

[13] Duraipandiyan V., Muniappan A. and Savarimthu I., 2006. Antimicrobial Activity of some Ethnomedicinal Plants Used by Paliyer Tribe from Tamil Nadu, India. Entomology Research Institute Loyola College Chennai. 60034, India.
[14] Duncan D. B., 1955. New Multiple Range Test. Biometry, 11: $1-48$.

[15] Tuhin J., Zinnat A. B. and Sayeeda S., 2007. Effect of Neem Oil on Some Pathogenic Bacteria. Bangdalesh Journal of Pharmacology, 2 (2): 71-72.

[16] Steel, R. G. D. and Torrie, J. H., 1984. Principles and procedures of statistics. Inten. student ed. Tokyo: McGraw Hill.

[17] Etim N. N., Williams E. D., Akpabio U. and Offiong E. E. A., 2014. Haematological parameters and factors affecting their values. Agricultural Science, 2 (1): 37-47.

[18] Isaac L. J., Abah G., Akpan B. and Ekaette I. U., 2013. Haematological properties of different bredds and sexes of rabbits. Proceeding of the 18th Annual conference of Animal Science Associated of Nigeria. 24-27.

[19] Babatunde G. M., Fajimi A. O. and Oyejide A. O., 1992. Rubber seed oil versus palm oil in broiler chicken diets: effect on performance, nutrient digestibility, haematology and carcass characteristics. Animal feed Science and Technology, 35: 133-146.

[20] Njidda A. A. and Isidahomen C. E., 2010. Hematology, blood chemistry and carcass characteristics of growth rabbits fed grasshopper meal as a substitute for fosh meal. Pakistan Veterinary Journal, 30 (1): 7-12.

[21] Yasar N. F., Uylas M. U., Baspinar M. Sarsilmaz H., Ates E., Erkasap S. and Sahin A., 2016. Evaluating the use of heamatological parameters in staging hidradenitis suppurativa. Wounds, 28 (11): 87-91.

[22] Vivian U., Oleforuh-Okoleh, Harriet M., Ndofor-Foleng, Salomon O., Olorunleke and Joseph O. U., 2015. Evaluation of growth performance, haematological and serum biochemical responses of broiler chickens to aqueous extract of ginger and garlic. Journal of Agricultural Science, 7 (4): $167-173$.

[23] Odoh L. I. and Lawrence L., 2015. Effects of varying levels of neem (Azadirachta indica) leqf meql in layer diets on the heamatological and serological indices, and faecal bacteria counts of layers. Journal of Natural Sciences Research, 5 (4): $37-44$

[24] Almosni-Le Sueur F., Dolz R., Natalia Majo N., 2011. Autopsie des volailles. Edt. Point Vétérinaire. Collection: Atlas Point Vétérinaire. 110p.

[25] Divya K., Ankit K., Tripathi J. S. and Tiwari S. K., 2013. Evaluating anti-asthmatic effect of polyherbal ayurvedic drug bharangyadi on respiratory mechanics using matlab. International Research Journal of Pharmacy, 4 (2): 167-169.

[26] Abalaka M., Oyewole O. A. and Kolawole A. R., 2012. Antibacterial Activities of Azadirachta indica against Some Bacterial Pathogens. Advances in Life Sciences, 2 (2): 5-8. 